\title{
Probing the ArcA regulon under aerobic/ROS conditions in Salmonella enterica serovar Typhimurium
}

\author{
Eduardo H Morales ${ }^{1,3,4 \dagger}$, Bernardo Collao ${ }^{1 \dagger}$, Prerak T Desai ${ }^{2}$, Iván L Calderón ${ }^{1}$, Fernando Gil ${ }^{1}$, Roberto Luraschi ${ }^{1}$, \\ Steffen Porwollik², Michael McClelland ${ }^{2}$ and Claudia P Saavedra ${ }^{1 *}$
}

\begin{abstract}
Background: Hydrogen peroxide $\left(\mathrm{H}_{2} \mathrm{O}_{2}\right)$ is a reactive oxygen species (ROS), which is part of the oxidative burst encountered upon internalization of Salmonella enterica serovar Typhimurium (S. Typhimurium) by phagocytic cells. It has previously been established that, the ArcAB two-component system plays a critical role in ROS resistance, but the genes regulated by the system remained undetermined to date. We therefore investigated the ArcA regulon in aerobically growing $\mathrm{S}$. Typhimurium before and after exposure to $\mathrm{H}_{2} \mathrm{O}_{2}$ by querying gene expression and other physiological changes in wild type and $\triangle \operatorname{arcA}$ strains.

Results: In the $\triangle a r c A$ strain, expression of 292 genes showed direct or indirect regulation by ArcA in response to $\mathrm{H}_{2} \mathrm{O}_{2}$, of which 141 were also regulated in aerobiosis, but in the opposite direction. Gene set enrichment analysis (GSEA) of the expression data from WT and $\triangle$ arcA strains, revealed that, in response to $\mathrm{H}_{2} \mathrm{O}_{2}$ challenge in aerobically grown cells, ArcA down regulated multiple PEP-PTS and ABC transporters, while up regulating genes involved in glutathione and glycerolipid metabolism and nucleotide transport. Further biochemical analysis guided by GSEA results showed that deletion of arcA during aerobic growth lead to increased reactive oxygen species (ROS) production which was concomitant with an increased $\mathrm{NADH} / \mathrm{NAD}^{+}$ratio. In absence of ArcA under aerobic conditions, $\mathrm{H}_{2} \mathrm{O}_{2}$ exposure resulted in lower levels of glutathione reductase activity, leading to a decreased GSH (reduced glutathione)/GSSG (oxidized glutathione) ratio.
\end{abstract}

Conclusion: The ArcA regulon was defined in 2 conditions, aerobic growth and the combination of peroxide treatment and aerobic growth in S. Typhimurium. ArcA coordinates a response that involves multiple aspects of the carbon flux through central metabolism, which ultimately modulates the reducing potential of the cell.

Keywords: ArcAB two-component system, Oxidative stress, Hydrogen peroxide resistance

\section{Background}

Salmonella enterica serovar Typhimurium (S. Typhimurium) is a Gram-negative, facultative anaerobe and intracellular bacterium that causes gastroenteritis, bacteremia and enteric fever in the murine model [1]. During its infective cycle, $S$. Typhimurium is internalized by phagocytes where it is exposed to a series of antimicrobial compounds including reactive oxygen species (ROS) which trigger the production of superoxide $\left(\mathrm{O}_{2}^{-}\right)$by phagocytic NADPH

\footnotetext{
* Correspondence: csaavedra@unab.cl

${ }^{\dagger}$ Equal contributors

'Laboratorio de Microbiología Molecular, Facultad Ciencias Biológicas, Universidad Andres Bello, Santiago, Chile

Full list of author information is available at the end of the article
}

oxidase. $\mathrm{O}_{2}{ }^{-}$is unstable with a half life in the order of milliseconds, and under acidic conditions, as those found within the Salmonella containing vacuole (SCV), two molecules of $\mathrm{O}_{2}^{-}$react to generate $\mathrm{H}_{2} \mathrm{O}_{2}$ [2]. Additionally, the $S$. Typhimurium genome codes for both cytoplasmic $(\operatorname{sod} A$ and $\operatorname{sodB})$ and periplasmic $(\operatorname{sod} C I$ and $\operatorname{sod} C I I)$ superoxide dismutases, that catalyze the generation of $\mathrm{H}_{2} \mathrm{O}_{2}$ and molecular oxygen from $\mathrm{O}_{2}^{-}$[3-5].

The response of the bacterium to $\mathrm{H}_{2} \mathrm{O}_{2}$ has been mostly related to the transcription factor OxyR [6], however, several studies in Escherichia coli (E. coli), $S$. Typhimurium, S. Enteritidis and Haemophilus influenzae indicate that the response regulator ArcA is required for

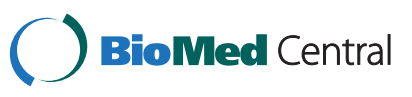


$\mathrm{H}_{2} \mathrm{O}_{2}$ resistance [7-10]. Furthermore, in E. coli $\mathrm{H}_{2} \mathrm{O}_{2}$ resistance depends on the cognate sensor ArcB [7]. The ArcAB two-component system is composed of the response regulator ArcA and the hybrid sensor kinase ArcB $[11,12]$. ArcAB responds to shifts in oxygen concentration $[13,14]$, however, the signal that activates the system remains elusive since some studies show no correlation between $\mathrm{ArcAB}$ activity and the ubiquinone pool [13], while others indicate that the system's activity depends on the ubiquinone and/or menaquinone pools [15-17]. Upon reduction of the redox-active cysteine residues between two monomers, ArcB undergoes autophosphorylation in an ATP-dependent intramolecular reaction at a conserved histidine residue located at position 292 [18,19]. The signal is transferred to residues D576 and $\mathrm{H} 717$ of ArcB and finally to residue D54 of ArcA $[12,19,20]$. Phosphorylated ArcA (ArcA-P) forms a tretamer of dimers in a 1:1 ratio of ArcA and ArcA-P, which binds to promoter regions, thereby regulating gene expression $[21,22]$.

Several studies in E. coli, S. Typhimurium, H. influenzae and Shewanella oneidensis have used global gene expression profiling to determine the ArcA regulon under anaerobic conditions, showing that the effect of ArcA is pleiotropic and coordinates a response that includes changes in cellular metabolism, motility and chromosomal replication, among others [8,10,23-26]. In $S$. Typhimurium 14028 s grown under anaerobic conditions, ArcA regulates either directly or indirectly more than 392 genes. Additionally, an $\operatorname{arc} A$ mutant has a longer doubling time than the wild type strain, lacks flagella, is non-motile and remains fully virulent [8].

In contrast to the vast amount of information about the role of ArcA in anaerobiosis, little is known about the genes or biochemical processes that ArcA regulates in response to $\mathrm{H}_{2} \mathrm{O}_{2}$. Previous studies have mainly shown that $\operatorname{arc} A$ or $\operatorname{arcB}$ mutant strains are more sensitive to the toxic compound [8-10]. One study conducted in $E$. coli used a proteomic approach and determined that ArcA regulates the expression of fliC, oppA and gltI in response to $\mathrm{H}_{2} \mathrm{O}_{2}$ [7], while in $S$. Typhimurium ArcA negatively regulates $o m p D$ and $o m p W[27,28]$. To gain further insights into the role of ArcA in ROS resistance, we compared transcriptional changes in $S$. Typhimurium 14028 s wild-type and $\triangle a r c A$ strains with and without peroxide exposure under aerobic conditions. As expected, the $\triangle a r c A$ mutation affected multiple pathways confirming that ArcA has a pleiotropic effect and plays a role as a global regulator. Interestingly, the genes regulated by ArcA in response to $\mathrm{H}_{2} \mathrm{O}_{2}$ differ from those regulated under anaerobic conditions [8]. A Gene Set Enrichment Analyses using the KEGG database predicted that 10 pathways were up-regulated and 2 down-regulated by ArcA in response to $\mathrm{H}_{2} \mathrm{O}_{2}$ treatment in aerobiosis. Finally, biochemical analyses showed that under aerobic conditions ArcA modulates the redox potential of the cell by regulating the levels of NADH and of intracellular ROS. After $\mathrm{H}_{2} \mathrm{O}_{2}$ exposure under aerobic conditions, ArcA was found to regulate turnover of reduced glutathione (GSH).

\section{Methods}

\section{Bacterial strains and growth conditions}

Pre-cultures of strains 14028 s wild type and $\triangle \operatorname{arc} A$ were streaked from cryo-vials stored at $-80^{\circ} \mathrm{C}$ onto LB agar plates and allowed to grow at $37^{\circ} \mathrm{C}$ for $12 \mathrm{~h}$. One colony was picked and grown in a $250 \mathrm{ml}$ Erlenmeyer flask containing $25 \mathrm{ml}$ of $\mathrm{LB}$ broth for $16 \mathrm{~h}$ at $37^{\circ} \mathrm{C}$ on a rotary shaker at $200 \mathrm{rpm}$. Exactly $500 \mu \mathrm{l}$ of the cultures were then transferred into $500 \mathrm{ml}$ Erlenmeyer flasks containing $50 \mathrm{ml}$ of LB broth and grown in a temperature controlled rotary shaker at $200 \mathrm{rpm}$ (LSI-3016R, Labtech Shaking Incubator, Indonesia). Optical density $\left(\mathrm{OD}_{600}\right)$ was measured until reaching the desired $\mathrm{OD}_{600}$ for treatment with $\mathrm{H}_{2} \mathrm{O}_{2}(\sim 0.4$, corresponding to an incubation time of about $2.5 \mathrm{~h}$ ). These conditions closely resemble those used in a previous study with $E$. coli, where $50 \mathrm{ml}$ of culture grown at $200 \mathrm{rpm}$ in a shaking incubator at $37^{\circ} \mathrm{C}$ to an $\mathrm{OD}_{546}$ of $\sim 0.4$ exhibited a $\mathrm{pO}_{2}$ of $\geq 90 \%$ [29]. Solid media contained agar $\left(20 \mathrm{~g} \mathrm{l}^{-1}\right)$, and plates were incubated at $37^{\circ} \mathrm{C}$. When necessary, growth media was supplemented with the appropriate antibiotics.

\section{Microarray analysis}

Overnight cultures of strains 14028 s and $\triangle \operatorname{arc} A$ were diluted (1:100) and cells were grown to $\mathrm{OD}_{600} \sim 0.4$ as described. At this point, $\mathrm{H}_{2} \mathrm{O}_{2}(1 \mathrm{mM})$ was added and cells were grown for $20 \mathrm{~min}$. Control cells received no treatment. Experiments were performed in triplicate on different days. After exposure to the toxic compound, $5 \mathrm{ml}$ of ice cold 5\% (v/v) phenol pH 4.3 / 95\% (v/v) ethanol was added to $25 \mathrm{ml}$ of culture and left on ice for $20 \mathrm{~min}$. Subsequently, $8 \mathrm{ml}$ of this solution were centrifuged for $10 \mathrm{~min}$ at $8000 \mathrm{rpm}$, the supernatant was removed and the bacterial pellet was resuspended with $200 \mu \mathrm{l}$ of $10 \mathrm{mM}$ Tris- $\mathrm{HCl}(\mathrm{pH}$ 8.0) that included $4 \mu \mathrm{l}$ of lysozyme $(50 \mathrm{mg} / \mathrm{ml})$. The reaction was incubated for $10 \mathrm{~min}$ at $37^{\circ} \mathrm{C}$, and total RNA was extracted using the High Pure RNA Isolation kit (Roche) following the manufacturer's instructions. RNA was eluted in $105 \mu$ l of water and treated with DNaseI (Roche) at $37^{\circ} \mathrm{C}$ for $30 \mathrm{~min}$. Total RNA was recovered using the Qiagen RNeasy kit (Qiagen), following the manufacturer's instructions. RNA was eluted in $80 \mu \mathrm{l}$ and subjected to a second round of DNaseI treatment (Ambion Turbo DNA-free kit) at $37^{\circ} \mathrm{C}$ for $30 \mathrm{~min}$, purified, recovered using the Qiagen RNeasy kit (Qiagen) following the manufacturer's instructions and eluted in $55 \mu \mathrm{l}$ of water. 
Exactly $20 \mu \mathrm{g}$ of total RNA were used for labeling with Cy3 or Cy5. Briefly, the RNA volume was adjusted to $30 \mu \mathrm{l}, 2 \mu \mathrm{l}$ of random hexamers $\mathrm{N}_{6}($ Sigma, $2 \mu \mathrm{g} / \mu \mathrm{l})$ were added and the mixture was incubated for $10 \mathrm{~min}$ at $70^{\circ} \mathrm{C}$. Subsequently, cDNA was generated using Superscript II (Invitrogen) following the manufacturer's instructions. Final nucleotide concentrations of the reaction were $0.5 \mathrm{mM}$ dATP, dTTP, dGTP and $0.2 \mathrm{mM}$ dCTP. After addition of the master mix, $4 \mu \mathrm{l}$ of $5 \mathrm{mM}$ dye labeled $\mathrm{dCTP}(\mathrm{Cy} 3$ or $\mathrm{Cy} 5)$ were added to the reaction and the mixture was incubated at $42^{\circ} \mathrm{C}$ for $60 \mathrm{~min}$. After this time, $2 \mu \mathrm{l}$ of Superscript II were added and the reaction was incubated at $42^{\circ} \mathrm{C}$ for an additional $60 \mathrm{~min}$. The reaction was stopped by adding $3 \mu \mathrm{l}$ of $1 \mathrm{M} \mathrm{NaOH}$ and incubating at $70^{\circ} \mathrm{C}$ for $10 \mathrm{~min}$. The $\mathrm{pH}$ was neutralized by adding $3 \mu \mathrm{l}$ of $1 \mathrm{M} \mathrm{HCl}$. The labeled cDNA was purified using the Qiagen PCR purification kit following the manufacturer's instructions. The purified labeled cDNA $(4 \mu \mathrm{g})$ was hybridized to $\mathrm{a} \sim 387.000$ 50-mer NimbleGen microarray (Roche NimbleGen), tiling the S. Typhimurium 14028s genome at overlapping intervals of about 12 bases on both strands, as previously described [30].

\section{Data acquisition and analysis}

Arrays were scanned using a GenePix 4000B laser scanner (Molecular Devices, Sunnyvale, California) at $5 \mu \mathrm{m}$ resolution. Signal intensities were quantified using NimbleScan software v2.4 (Roche NimbleGen). Intensity values were background subtracted, normalized within (median) and between (quantile) the arrays using WebarrayDB [31], and converted to $\log _{2}$ values. For each array, the background was calculated as follows: $\log _{2}$ median intensity value for negative control probes $+(3 *$ $\log _{2}$ intensity value standard deviation negative control probes). Negative control probes correspond to the probes located on the non-coding strand of each gene in the array. Genes with intensity values over the background were included in the analysis. After array data acquisition and normalization, two-way ANOVA was performed using MeV TM4 software [32], to determine uncorrected p-values. For the analysis, two categories were considered (genotype and treatment), each with two sub-categories. False Discovery Rate (FDR) adjusted q values were calculated using QVALUE in Bioconductor [33]. Genes with a q value $\leq 0.05$ for interaction and a ratio of $\geq 2$ between the fold change of strains 14028 s wild type and $\triangle \operatorname{arc} A$ ((wild type treated/wild type control)/( $\triangle a r c A$ treated/ $\triangle \operatorname{arc} A$ control)) were considered to be differentially regulated in response to $\mathrm{H}_{2} \mathrm{O}_{2}$. Genes with a q-value of $\leq 0.05$ for genotype and a fold change of $\geq 2$ between strains $\triangle \operatorname{arc} A$ and wild type ( $\triangle \operatorname{arc} A$ control/wild type control) without treatment were considered to be differentially regulated in aerobiosis. The microarray data has been deposited in GEO (http://www.ncbi.nlm.nih. gov/geo/) and is accessible via GEO Accession Number GSE34134.

Prediction of metabolic pathways altered in the different strains by treatment with $\mathrm{H}_{2} \mathrm{O}_{2}$ or due to the mutation of $\operatorname{arc} A$ was performed using the software Gene Set Enrichment Analysis (GSEA) [34], with the KEGG database for $S$. Typhimurium LT2 as a reference. Briefly, GSEA is a computational method that determines whether an a priori defined set of genes shows statistically significant, concordant differences between two biological states [34]. To determine the pathways regulated by ArcA in response to $\mathrm{H}_{2} \mathrm{O}_{2}$, the $\log _{2}$ values of all replicas were averaged and treated as follows: ( $\log _{2}$ 14028s wild type $\mathrm{H}_{2} \mathrm{O}_{2}$ aerobic - $\log _{2} 14028$ s wild type aerobic) - $\left(\log _{2} \triangle \operatorname{arc} A \mathrm{H}_{2} \mathrm{O}_{2}\right.$ aerobic - $\log _{2} \triangle \operatorname{arc} A$ aerobic). Positive Normalized Enrichment Score (NES) values represent pathways up-regulated by ArcA, while negative NES values represent pathways negatively regulated upon $\mathrm{H}_{2} \mathrm{O}_{2}$ treatment under aerobic conditions. To determine the pathways regulated under aerobic conditions, the $\log _{2}$ values of all replicas of untreated cells were averaged and treated as follows: $\left(\log _{2} \triangle \operatorname{arc} A\right.$ aerobic - $\log _{2} 14028$ s wild type aerobic). Pathways with an FDR of $\leq 0.25$ as determined by GSEA were considered to present significant changes.

\section{Real time quantitative RT-PCR}

qRT-PCR was performed using the primers listed in Additional file 1: Table S1 as previously described [28], with a minor modification of the PCR program. Briefly, relative quantification was performed using Brilliant II SYBR Green QPCR Master Reagent Kit and the $\mathrm{M} \times 3000 P$ detection system (Stratagene). 16S rRNA was used for normalization. The reaction mixture was carried out in a final volume of $20 \mu \mathrm{l}$ containing $1 \mu \mathrm{l}$ of diluted cDNA (1:1000), $0.24 \mu \mathrm{l}$ of each primer $(120 \mathrm{nM}), 10 \mu \mathrm{l}$ of $2 \times$ Master Mix, $0.14 \mu \mathrm{l}$ of diluted ROX (1:200) and $8.38 \mu \mathrm{l}$ of $\mathrm{H}_{2} \mathrm{O}$. The reaction was performed under the following conditions: $10 \mathrm{~min}$ at $95^{\circ} \mathrm{C}$ followed by 40 cycles of $30 \mathrm{~s}$ at $95^{\circ} \mathrm{C}, 30 \mathrm{~s}$ at $58^{\circ} \mathrm{C}$ and $30 \mathrm{~s}$ at $72^{\circ} \mathrm{C}$. Finally, a melting cycle from $65^{\circ} \mathrm{C}$ to $95^{\circ} \mathrm{C}$ was performed to check for amplification specificity. Amplification efficiency was calculated from a standard curve constructed by amplifying serial dilutions of RT-PCR products for each gene. These values were used to obtain the fold-change in expression for the gene of interest normalized with $16 \mathrm{~S}$ levels according to Pfaffl [35].

\section{Promoter analysis}

A positional weight matrix was generated using the ArcA-binding sites predicted in $E$. coli for which footprinting experiments are available reviewed in [36]. Additionally, the binding sites predicted for members of the ArcA regulon in S. Typhimurium 14028s in anaerobiosis 
were also included [8], as was that of the $o m p W$ promoter region, which was shown to be functional [28]. The upstream sequences of the genes regulated by ArcA in response to aerobiosis or $\mathrm{H}_{2} \mathrm{O}_{2}$ exposure under aerobic conditions (Additional file 2: Table S2) were retrieved (positions -400 to -1 with respect to the translation start site) from the sequenced and annotated genome of $S$. Typhimurium 14028s [37]. Promoter regions with less than $20 \mathrm{nt}$ between the translation start site of the ORF under analysis and the end or start of the upstream ORF were not included in the analysis. Binding sites at the promoter regions of genes regulated by ArcA in response to aerobiosis or $\mathrm{H}_{2} \mathrm{O}_{2}$ exposure under aerobic conditions (Additional file 2: Table S2) were predicted using the Matrix-scan software [38] available at http:// rsat.ulb.ac.be/. The parameters used for the analysis were those given by default by the software. Binding sites with a $\mathrm{p}$-value of $\leq 0.0001$ were considered significant and reported as predicted ArcA binding sites.

\section{Biochemical determinations}

Overnight cultures of strains 14028s wild type and $\triangle \operatorname{arc} A$ were diluted $(1: 100)$ and cells were grown to $\mathrm{OD}_{600} \sim 0.4$. At this point, $\mathrm{H}_{2} \mathrm{O}_{2}(1.0 \mathrm{mM})$ was added and cells were grown for $20 \mathrm{~min}$. Control cells received no treatment. Experiments were performed in triplicate on different days. After treatment, $6 \mathrm{ml}$ of cultures were withdrawn for each analysis and used for measurement of NADH, glutathione (GSH) and glutathione reductase (GR) activity. NADH was measured using commercially available kits by Abcam. The ratio between reduced glutathione and oxidized glutathione (GSH/GSSG) and GR activity were measured using commercially available kits by Cayman Chemicals. In all cases, measurements were performed following the instructions provided by the manufacturers without modifications.

Measurement of intracellular ROS was performed using the oxidant-sensitive probe $\mathrm{H}_{2} \mathrm{DCFDA}$, as previously described, with minor modifications [39]. Briefly, aerobically grown cells in $\mathrm{LB}$ at $\mathrm{OD}_{600} \sim 0.4$ were incubated with $10 \mu \mathrm{M} \mathrm{H}_{2}$ DCFDA. At 10 min intervals aliquots were taken, washed with $10 \mathrm{mM}$ potassium phosphate buffer, $\mathrm{pH}$ 7.0, resuspended in the same buffer, and disrupted by sonication. Cell extracts $(100 \mu \mathrm{l})$ were mixed with $1 \mathrm{ml}$ phosphate buffer and fluorescence was measured using a TECAN Infinite 200 PRO Nanoquant microplate reader (excitation, $480 \mathrm{~nm}$; emission, $520 \mathrm{~nm}$ ). Emission values were normalized based on the bacterial concentration as determined by the Optical Density (OD) of the culture at $600 \mathrm{~nm}$.

\section{Results}

To analyze the role of ArcA in the transcriptional response to aerobiosis and $\mathrm{H}_{2} \mathrm{O}_{2}$, the ArcA regulon of
S. Typhimurium was determined by microarray analysis. Expression profiles were measured from three independent samples of aerobically grown wild-type (14028s) and $\triangle \operatorname{arc} A$ strains with or without $1 \mathrm{mM} \mathrm{H}_{2} \mathrm{O}_{2}$. After normalization, 3949 genes showed intensity values over the background in at least one array and were included in the analysis. The results were validated by randomly selecting eight genes and measuring the transcript levels by qRTPCR (Additional file 1: Table S1). A statistically significant correlation was observed between microarray and qRTPCR data $\left(r^{2}=0.7, p\right.$-value $\left.\leq 0.0001\right)$, despite quantitative differences in the level of change, suggesting that the results obtained by microarray analysis reflect the actual changes in gene expression.

In the wild type strain, expression of 381 and 667 genes was up- or downregulated, respectively, in response to $\mathrm{H}_{2} \mathrm{O}_{2}$ under aerobic conditions (fold change $\geq 2$, FDR q-value treatment $\leq 0.05$, Additional file 2: Table S2). Several genes known to be upregulated by $\mathrm{H}_{2} \mathrm{O}_{2}$ and required for its resistance were among the upregulated genes in the wild type and $\triangle a r c A$ strains, including katE, katG and $m n t H$ [40]. A previous study investigated the effect of $\mathrm{H}_{2} \mathrm{O}_{2}$ on gene expression in a different $S$. Typhimurium strain, 4/74 [41]. That study found 309 genes to be upregulated after $\mathrm{H}_{2} \mathrm{O}_{2}$ exposure, and 428 genes to be downregulated. The concurrence with our results in strain 14028 s is about $30 \%: 119 / 381$ upregulated 14028 s genes and 191/667 downregulated 14028s genes had been found to be similarly regulated in strain $4 / 74$. The observed differences in the number of genes differentially expressed might be explained by several factors including $\mathrm{OD}_{600}$ of treatment (0.4 vs 0.1 ), time of $\mathrm{H}_{2} \mathrm{O}_{2}$ challenge ( $20 \mathrm{~min}$ vs $12 \mathrm{~min}$ ), threshold for considering a gene differentially expressed (fold change of $\geq 2$ vs $\geq 3$ ), and different $S$. Typhimurium strains used in the studies (14028s vs 4/74).

\section{Role of ArcA during aerobic conditions}

The expression of 220 and 122 genes was up- or downregulated, respectively, by ArcA under aerobic conditions (Additional file 2: Table S2). Comparison with the ArcA regulon of strain 14028s in anaerobiosis [8] showed that 63 genes were regulated under both conditions, but the expression of 38 genes was regulated in the opposite direction. Of the 220 genes upregulated by ArcA in aerobiosis, only 15 are positively regulated by ArcA under anaerobic conditions (Figure 1A), while of the 122 genes downregulated by ArcA under aerobic conditions, only 10 are also downregulated by ArcA in anaerobiosis (Figure 1B).

To deduce the biological pathways altered in the $\operatorname{arc} A$ mutant as compared to the aerobically grown wild type strain under aerobic conditions, a Gene Set Enrichment Analysis (GSEA) was performed using the KEGG database for $S$. Typhimurium LT2 as a reference. It should 

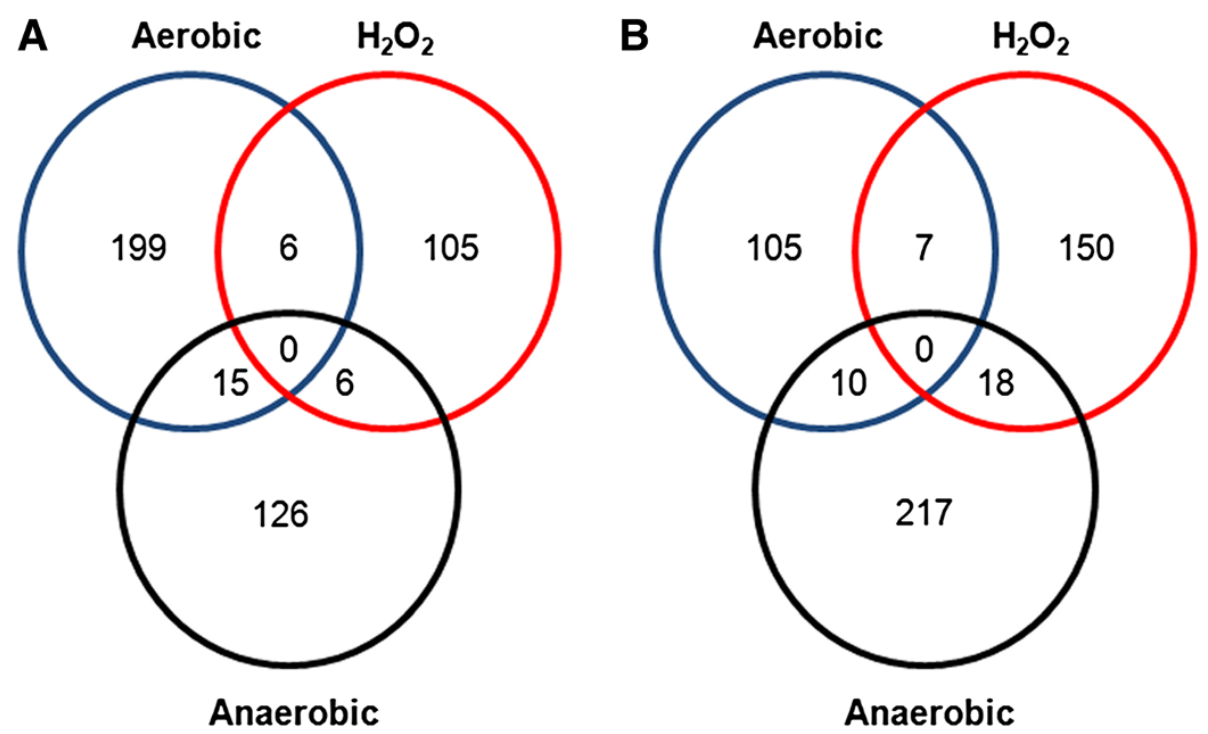

Figure 1 Overlap of the ArcA regulon in response to $\mathrm{H}_{2} \mathrm{O}_{2}$, aerobiosis and anaerobiosis. Numbers indicate the amount of genes that show statistically significant differential expression in a $\triangle a r c A$ mutant vs a wild type strain 14028 s in the respective condition. The number of genes (A) positively or (B) negatively regulated by ArcA in each condition is shown. Genes regulated by ArcA in anaerobiosis were obtained from [8]. Genes regulated by ArcA in aerobiosis with or without $\mathrm{H}_{2} \mathrm{O}_{2}$ are detailed in Additional file 2: Table S2. Genes with a fold change of $\geq 2$ and an FDR q value of $\leq 0.05$ for each category were considered to be differentially expressed.

be noted that to determine the pathways regulated by ArcA under aerobic conditions, we compared the transcript levels of the $\operatorname{arcA}$ mutant to those in the wild type strain $\left(\log _{2} \triangle \operatorname{arc} A\right.$ aerobic $-\log _{2}$ wild type aerobic). Thus, pathways repressed by ArcA possess positive NES values (i.e., $>0$, glycolysis), while pathways activated by ArcA have negative NES values (i.e., $<0$, ABC transporters). GSEA showed that 12 and 8 pathways were upor downregulated, respectively, by ArcA under aerobic conditions (Table 1). Among the pathways upregulated by ArcA were those implicated in the transport of amino acids and sugars, oligopeptides and metals, including PTS and ABC transporters, among others (Table 1, negative NES values). Under aerobic conditions, ArcA mainly repressed pathways implicated in central metabolism and nucleotide biosynthesis (Table 1, positive NES values). In particular, the transcript levels of genes encoding proteins of the payoff phase of glycolysis [42] and glycerolipid metabolism were higher in the $\operatorname{arcA}$ mutant grown under aerobic conditions than in strain $14028 \mathrm{~s}$ (Figure 2, Addition file 2 Table S2), including $p y k F$ (pyruvate kinase), aceEF-lpdA (pyruvate dehydrogenase complex), eno (enolase), $g l p D$ and $g l p A B C$ (glycerol 3phosphate dehydrogenase). The data suggests that the aerobically grown $\triangle a r c A$ mutant presents a higher flux through glycolysis and increased levels of NADH than the wild type strain. Interestingly, genes of the Krebs cycle, which are negatively regulated by ArcA under anaerobic conditions [8], were not repressed in aerobiosis (Table S2). Together, these results indicate that
ArcA has a major role in regulating gene expression under aerobic conditions and that the genes regulated in aerobiosis are different from those regulated in anaerobiosis.

\section{Role of ArcA in the response to $\mathrm{H}_{2} \mathrm{O}_{2}$ under} aerobic conditions

It has been well established that an aerobically grown $\triangle \operatorname{arcA}$ strain is sensitive to $\mathrm{H}_{2} \mathrm{O}_{2}$ treatment [7-10], however, the genes regulated by ArcA under this condition have not been determined. Our analysis shows that ArcA directly or indirectly regulates the expression of 292 genes in response to $\mathrm{H}_{2} \mathrm{O}_{2}$ in aerobically grown cells, 117 and 175 genes were up- or downregulated, respectively (Figure 1, Additional file 2: Table S2). Surprisingly, almost no correlation was observed between the genes regulated by ArcA in aerobiosis with or without $\mathrm{H}_{2} \mathrm{O}_{2}$ : only 6 genes were upregulated under both conditions (Figure 1A), while 7 genes were downregulated (Figure 1B). Furthermore, comparison of the ArcA regulon in aerobiosis, anaerobiosis [8] and aerobiosis with $\mathrm{H}_{2} \mathrm{O}_{2}$ showed that no genes were up or downregulated in all three conditions (Figure $1 \mathrm{~A}$ and $\mathrm{B}$ ). This suggests that the genes regulated by ArcA in response to various stimuli are different and do hardly overlap (Figure 1), which underscores the importance and versatility of ArcAmediated regulation.

To determine the pathways regulated by ArcA in response to $\mathrm{H}_{2} \mathrm{O}_{2}$ under aerobic conditions, the intensity values were treated as follows: $\left(\log _{2} 14028\right.$ s wild type 
Table 1 Pathways differentially regulated $(q \leq 0.25)$ by ArcA in response to $\mathrm{H}_{2} \mathrm{O}_{2}$ and aerobiosis as determined by GSEA

\begin{tabular}{|c|c|c|c|c|c|c|c|}
\hline \multirow[b]{2}{*}{ Gene set } & \multirow[b]{2}{*}{ Size of gene set ${ }^{A}$} & \multicolumn{2}{|c|}{ Genes regulated } & \multicolumn{2}{|c|}{ FDR q-value } & \multicolumn{2}{|c|}{$\mathrm{NES}^{\mathrm{H}}$} \\
\hline & & Aerobic $^{\mathrm{B}}$ & $\mathrm{H}_{2} \mathrm{O}_{2}^{\mathrm{C}}$ & Aerobic $^{\mathrm{D}}$ & $\mathrm{H}_{2} \mathrm{O}_{2}^{\mathrm{E}}$ & Aerobic $^{F}$ & $\mathrm{H}_{2} \mathrm{O}_{2}{ }^{\mathrm{G}}$ \\
\hline Glycerophospholipid metabolism & 25 & 5 & 5 & 0.001 & 0.000 & 2.16 & 2.29 \\
\hline Purine metabolism & 73 & 19 & 35 & 0.003 & 0.000 & 2.06 & 2.22 \\
\hline Pyrimidine metabolism & 50 & 14 & 18 & 0.044 & 0.003 & 1.79 & 2.02 \\
\hline Lipopolisaccharide biosynthesis & 26 & & 17 & & 0.004 & & 1.98 \\
\hline Glutathione metabolism & 16 & & 8 & & 0.005 & & 1.94 \\
\hline Bacterial invasion of epithelial cells & 8 & 8 & 5 & 0.002 & 0.012 & -1.9 & 1.87 \\
\hline Glycolysis/gluconeogenesis & 33 & 10 & 10 & 0.250 & 0.022 & 0.46 & 1.81 \\
\hline Biosynthesis of siderophore group non-ribosomal peptides & 5 & & 4 & & 0.067 & & 1.69 \\
\hline Glycerolipid metabolism & 10 & 1 & 1 & 0.083 & 0.109 & 1.68 & 1.6 \\
\hline Flagellar assembly & 34 & & 7 & & 0.189 & & 1.5 \\
\hline Phosphotransferase system (PTS) & 32 & 17 & 17 & 0.001 & 0.000 & -1.88 & -2.26 \\
\hline ABC transporters & 124 & 46 & 29 & 0.005 & 0.022 & -1.83 & -1.86 \\
\hline Salmonella infection & 16 & 8 & & 0.001 & & -2.04 & \\
\hline Bacterial secretion system & 28 & 12 & & 0.005 & & -1.79 & \\
\hline Bacterial chemotaxis & 22 & 6 & & 0.049 & & -1.63 & \\
\hline Two-component system & 88 & 11 & & 0.096 & & -1.56 & \\
\hline Cyanoamino acid metabolism & 6 & 3 & & 0.129 & & -1.52 & \\
\hline Ascorbate and aldarate metabolism & 8 & 3 & & 0.117 & & -1.52 & \\
\hline Amino sugar and nucleotide sugar metabolism & 50 & 14 & & 0.213 & & -1.43 & \\
\hline Fructose and mannose metabolism & 34 & 14 & & 0.233 & & -1.43 & \\
\hline Starch and sucrose metabolism & 26 & 14 & & 0.244 & & -1.39 & \\
\hline Ribosome & 45 & 28 & & 0.004 & & 2.01 & \\
\hline Riboflavin metabolism & 8 & 3 & & 0.113 & & 1.63 & \\
\hline Cysteine and methionine metabolism & 24 & 8 & & 0.137 & & 1.59 & \\
\hline
\end{tabular}

A Based on the KEGG database for S. Typhimurium LT2.

${ }^{\mathrm{B}}$ Number of genes predicted to contribute to the enrichment in aerobic growth in rich media.

${ }^{C}$ Number of genes predicted to contribute to the enrichment in response to $\mathrm{H}_{2} \mathrm{O}_{2}$.

${ }^{\mathrm{D}} \mathrm{q}$-value for the pathway predicted to be regulated by ArcA in aerobic growth in rich media.

${ }_{\mathrm{E}} \mathrm{q}$-value for the pathway predicted to be regulated by $\operatorname{ArcA}$ in response to $\mathrm{H}_{2} \mathrm{O}_{2}$.

${ }^{F}$ Normalized enrichment score for pathways under aerobic conditions. Positive values indicate pathways negatively regulated by ArcA, while negative values indicate pathways that are up-regulated by ArcA.

${ }^{G}$ Normalized enrichment score for pathways under aerobic conditions after $\mathrm{H}_{2} \mathrm{O}_{2}$ exposure. Positive values indicate pathways positively regulated by ArcA, while negative ones indicate pathways that are downregulated by ArcA.

${ }^{\mathrm{H}}$ Normalized enrichment score.

$\mathrm{H}_{2} \mathrm{O}_{2}$ aerobic - $\log _{2} 14028 \mathrm{~s}$ wild type aerobic) - $\left(\log _{2}\right.$ $\triangle \operatorname{arcA~} \mathrm{H}_{2} \mathrm{O}_{2}$ aerobic - $\log _{2} \triangle \operatorname{arcA}$ aerobic). Therefore, in contrast to the pathways regulated by ArcA under aerobic conditions, the pathways positively regulated by ArcA in response to $\mathrm{H}_{2} \mathrm{O}_{2}$ under aerobic conditions have positive NES values, while the pathways negatively regulated by ArcA in response to $\mathrm{H}_{2} \mathrm{O}_{2}$ under aerobic conditions have negative NES values. Based on the transcriptomic data (Additional file 2: Table S2), GSEA deduced that 10 and 2 pathways were up- or downregulated, respectively, by ArcA in aerobically grown cells after $\mathrm{H}_{2} \mathrm{O}_{2}$ exposure (Table 1). The pathways deduced to be upregulated by ArcA in response to $\mathrm{H}_{2} \mathrm{O}_{2}$ are implicated in nucleotide and siderophore biosynthesis, central and glutathione metabolism, among others, while the pathways downregulated by ArcA were PTS and $\mathrm{ABC}$ transporters (Figure 2, Table 1). Interestingly, only one gene $(a h p F)$ required for $\mathrm{H}_{2} \mathrm{O}_{2}$ degradation was upregulated by ArcA in aerobiosis after $\mathrm{H}_{2} \mathrm{O}_{2}$ treatment (Additional file 2: Table S2), suggesting that ArcA is not required for ROS scavenging. Of particular interest are the genes most upregulated by ArcA in aerobiosis with $\mathrm{H}_{2} \mathrm{O}_{2}$ in the pathways of nucleotide and glutathione metabolism, coding for the alternative ribonucleotide reductase $(n r d E F)$ and glutathione reductase (gor). In addition, the gene coding for thioredoxin reductase $(\operatorname{tr} x B)$, required for reduction of oxidized thioredoxin $\left(\operatorname{Trx}-[\mathrm{S}]_{2}\right)$, was also upregulated by ArcA after peroxide 


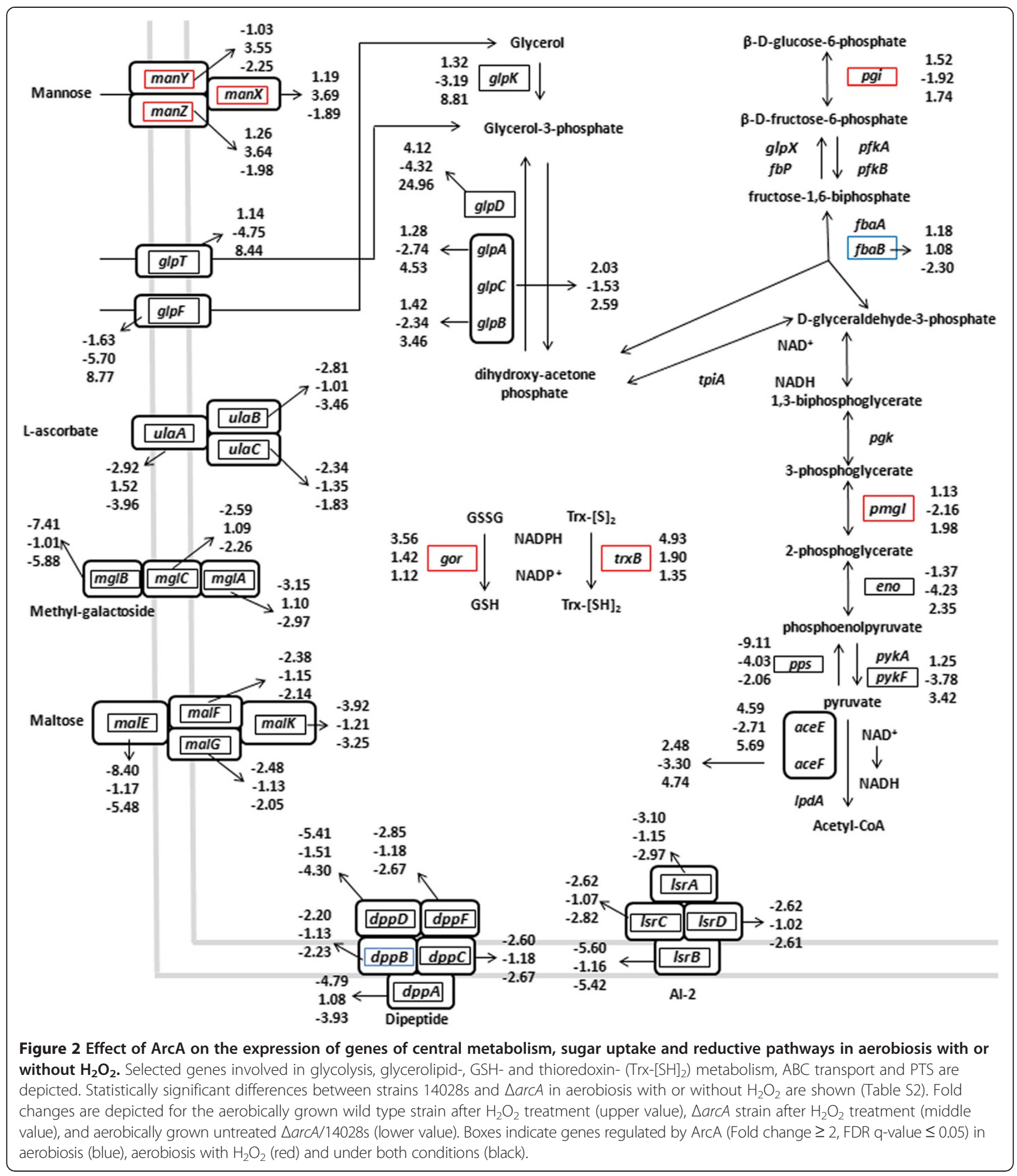

exposure. In E. coli, nrdEF is upregulated in response to $\mathrm{H}_{2} \mathrm{O}_{2}[43,44]$ and allows replication in iron-limiting conditions when manganese is present [44]. Gor and TrxB are required for the turnover of oxidized glutathione (GSSG) and $\operatorname{Trx}-[\mathrm{S}]_{2}$, respectively (reduction from GSSG to reduced glutathione (GSH), and $\operatorname{Trx}-[\mathrm{S}]_{2}$ to reduced thioredoxin (Trx- $\left.[\mathrm{SH}]_{2}\right)$, respectively), which participate in the reduction of disulfide bonds [45]. This suggests that in aerobically grown cells exposed to $\mathrm{H}_{2} \mathrm{O}_{2}$, ArcA regulates the GSH/GSSG and $\operatorname{Trx}-[\mathrm{S}]_{2} / \operatorname{Trx}-[\mathrm{SH}]_{2}$ ratio, modulating the redox status of the cell, and the expression of $n r d E F$. 


\section{Promoter analysis}

To determine the genes that may be directly regulated by $\operatorname{ArcA}$, we identified the subset of ArcA-dependently differentially expressed genes in aerobiosis with or without $\mathrm{H}_{2} \mathrm{O}_{2}$ with predicted ArcA-binding sites in the upstream regions (Additional file 2: Table S2), using the sequenced genome of $S$. Typhimurium 14028s [37] and Matrix-scan [38], as detailed in Methods. The analysis predicted that ArcA directly regulates the expression of 6 genes in aerobiosis with $\mathrm{H}_{2} \mathrm{O}_{2}$ and 19 genes in aerobically grown cells (Table 2 ).

\section{Biochemical analysis of the $\triangle \operatorname{arc} A$ strain}

The microarray analysis predicted that in response to $\mathrm{H}_{2} \mathrm{O}_{2}$ under aerobic conditions, ArcA regulates the expression of genes implicated in GSH metabolism. It also predicted that in aerobiosis, ArcA regulates expression of genes coding proteins involved in glycolysis (Table 1 and Additional file 2: Table S2). To evaluate if the changes in gene expression correlated with changes in the products of these pathways, we determined the levels of $\mathrm{GSH}$, glutathione reductase (GR) activity, NADH and total intracellular ROS in the wild type and $\triangle \operatorname{arcA}$ strains in aerobiosis with and without $\mathrm{H}_{2} \mathrm{O}_{2}$.

The gene gor was upregulated by ArcA under aerobic conditions with $\mathrm{H}_{2} \mathrm{O}_{2}$ (Figure 2, Additional file 2: Table S2), therefore decreased levels of both GSH and GR activity in the $\operatorname{arc} A$ mutant exposed to $\mathrm{H}_{2} \mathrm{O}_{2}$ under aerobic conditions were expected. The levels of GR activity were indeed lower in the aerobically grown $\triangle \operatorname{arc} A$ strain after $\mathrm{H}_{2} \mathrm{O}_{2}$ treatment, although the levels of GR activity were also decreased in the $\triangle a r c A$ mutant under aerobic conditions (Figure 3A). GSH remained almost unaltered in the wild type strain after treatment with the toxic compound, conversely, the aerobically grown $\triangle \operatorname{arc} A$ mutant treated with $\mathrm{H}_{2} \mathrm{O}_{2}$ showed significantly reduced levels of GSH and increased GSSG, consistent with lower GR activity (Figure 3A and B). In agreement, the GSH/GSSG ratio was lower in the aerobically grown $\triangle \operatorname{arc} A$ strain after $\mathrm{H}_{2} \mathrm{O}_{2}$ treatment (Figure $3 \mathrm{C}$ ), while the levels of total glutathione were similar between the wild type and $\triangle \operatorname{arc} A$ mutant strains (4.68 and $4.45 \mu \mathrm{mol} / \mathrm{mg}$. protein, respectively). This indicates that GSH turnover is altered in an aerobically grown $\triangle \operatorname{arc} A$ strain with $\mathrm{H}_{2} \mathrm{O}_{2}$ due to lower GR activity.

The transcript levels of genes coding the pyruvate dehydrogenase complex (PDH), proteins of the payoff phase of glycolysis [42] and sugar uptake were higher in the aerobically grown $\triangle a r c A$ mutant than in the wild type strain (Figure 2, Additional file 2: Table S2). This suggests that under aerobic conditions a $\triangle \operatorname{arc} A$ strain has a higher flux through glycolysis, which in turn could result in higher levels of acetyl-CoA and an elevated $\mathrm{NADH}$ generation in the Krebs cycle. As predicted, the
$\mathrm{NADH} / \mathrm{NAD}^{+}$ratio was significantly lowered in the aerobically grown wild type strain after peroxide treatment (Figure 3D), compared to untreated aerobically grown wild type cells. In the $\triangle \operatorname{arc} A$ mutant, the $\mathrm{NADH} / \mathrm{NAD}^{+}$ ratio was higher than in the wild type strain in aerobically grown cells before and after $\mathrm{H}_{2} \mathrm{O}_{2}$ treatment (Figure 3D). Although there was an overall decrease in the NADH/ $\mathrm{NAD}^{+}$ratio in the $\triangle \operatorname{arc} A$ strain after $\mathrm{H}_{2} \mathrm{O}_{2}$ treatment, the ratio remained 2 -fold higher than in wild type cells under aerobic conditions without $\mathrm{H}_{2} \mathrm{O}_{2}$ treatment.

In E. coli, one of the sources of $\mathrm{O}_{2}^{-}$is oxidation of the respiratory electron transport chain and the conversion of NADH to $\mathrm{NAD}^{+}$[46]. Since under aerobic growth conditions a $\triangle \operatorname{arcA}$ strain has higher levels of NADH (Figure 3D) and $n d h$ transcript than the wild type strain (Additional file 2: Table S2), we hypothesized that a $\triangle \operatorname{arc} A$ mutant might present increased levels of total ROS. In agreement, in an aerobically grown $\triangle \operatorname{arc} A$ strain, total ROS was increased as compared to the isogenic wild type strain under the same condition (Figure 3E), indicating that the absence of ArcA generates a metabolic imbalance which leads to increased levels of ROS.

In order to complement the $\triangle \operatorname{arc} A$ mutation, we first evaluated the mechanism by which ArcA regulates gene expression in response to ROS. Our results show that in $S$. Typhimurium 14028s, $\operatorname{arc} A$ expression is not increased either with $\mathrm{H}_{2} \mathrm{O}_{2}$ or hypochlorous acid (Additional file 1: Figure S1A). In addition, the levels of ArcA also remained constant after exposure to both ROS (Additional file 1: Figure S1B). This suggests that rather than changes in expression, ArcA is activated in response to ROS, most likely by phosphorylation of residue D54. To test this hypothesis, the $\triangle \operatorname{arc} A$ mutant strain was complemented in trans with the wild type gene and a version coding a substitution of residue D54 of ArcA (D54A), and the number of colony forming units $(\mathrm{CFU} / \mathrm{ml})$ was determined after $\mathrm{H}_{2} \mathrm{O}_{2}$ exposure. As predicted, only complementation with the wild type gene resulted in similar CFU/ml as in strain $14028 \mathrm{~s}$ (Additional file 1: Figure S1C), however, there were also differences in the number of $\mathrm{CFU} / \mathrm{ml}$ at the initial time points. This is most likely caused by increased levels of ArcA due to complementation with a high copy number vector. Since the effect of ArcA is pleiotropic and its levels remain constant throughout all stresses evaluated (Additional file 1: Figure S1 A and B), achieving wild type levels of ArcA is required to properly address its role in the response to ROS.

\section{Discussion}

Several reports have demonstrated that the global regulator ArcA is required for $\mathrm{H}_{2} \mathrm{O}_{2}$ resistance [7-10], however, only a few have evaluated its role on regulating gene expression under this condition $[27,28]$. One study conducted in $E$. coli used a proteomic approach to 
Table 2 Genes differentially expressed by ArcA under aerobic conditions with or without $\mathrm{H}_{2} \mathrm{O}_{2}$ that have predicted ArcA binding sites

\begin{tabular}{|c|c|c|c|c|c|c|c|c|c|c|}
\hline \multirow{2}{*}{$\begin{array}{c}\text { Gene ID } \\
\text { LT2 }\end{array}$} & \multirow{2}{*}{$\begin{array}{l}\text { Gene ID } \\
\text { 14028s }\end{array}$} & \multirow[t]{2}{*}{$\begin{array}{l}\text { Gene } \\
\text { name }\end{array}$} & \multicolumn{2}{|c|}{$\begin{array}{l}\text { Fold change } \\
\mathrm{H}_{2} \mathrm{O}_{2} / \text { control }\end{array}$} & \multirow{2}{*}{$\begin{array}{c}\text { Fold change } \\
\text { control } \\
\Delta a r c A / \\
14028 s \\
\end{array}$} & \multirow{2}{*}{ Strand } & \multirow[t]{2}{*}{ Position $^{A}$} & \multirow{2}{*}{$\begin{array}{l}\text { Sequence } \\
5^{\prime}-3^{\prime}\end{array}$} & \multirow[t]{2}{*}{$p$-value ${ }^{B}$} & \multirow[t]{2}{*}{ Function } \\
\hline & & & $14028 \mathrm{~s}$ & $\Delta \operatorname{arcA}$ & & & & & & \\
\hline \multirow[t]{2}{*}{ STM0958 } & \multirow{2}{*}{ STM14_1080. } & \multirow[t]{2}{*}{$\operatorname{trx} B$} & \multirow[t]{2}{*}{4.93} & \multirow[t]{2}{*}{1.9} & \multirow[t]{2}{*}{1.35} & - & 94 & GTTAACAATATGTGT & $1.00 \mathrm{E}-05$ & \multirow[t]{2}{*}{ thioredoxin reductase } \\
\hline & & & & & & + & 85 & GTTAACAAAATCGTT & 5.70E-05 & \\
\hline STM1520 & STM14_1838 & marR & 1.75 & -1.38 & -1.02 & - & 73 & GTCAACTAAATGAAT & $9.50 \mathrm{E}-05$ & $\begin{array}{l}\text { DNA-binding transcriptional } \\
\text { repressor MarR }\end{array}$ \\
\hline STM1586 & STM14_1918 & - & 5.55 & 2.75 & 1.06 & + & 171 & GTTAAGAAAATGTGC & $9.50 \mathrm{E}-05$ & $\begin{array}{l}\text { putative periplasmic } \\
\text { protein }\end{array}$ \\
\hline STM3216 & STM14_3893 & tsr & 1.17 & -1.65 & -1.31 & - & 198 & GTTAACCATTTCTTA & $8.10 \mathrm{E}-06$ & $\begin{array}{l}\text { putative methyl-accepting } \\
\text { chemotaxis protein }\end{array}$ \\
\hline STM2445 & STM14_3003 & uсpA & -5.34 & -1.83 & -1.86 & + & 44 & GTTAATGGAGTGTAA & $1.20 \mathrm{E}-05$ & short chain dehydrogenase \\
\hline STM1795 & STM14_2170 & gluD & -6.28 & -1.34 & -1.94 & - & 121 & GTTAACTATCCGCTA & $9.50 \mathrm{E}-05$ & $\begin{array}{l}\text { putative glutamic } \\
\text { dehyrogenase-like protein }\end{array}$ \\
\hline STM4087 & STM14_4913 & glpF & -1.63 & -5.7 & 8.77 & + & 217 & GTTAATGAAATGATT & $1.00 \mathrm{E}-05$ & glycerol diffusion \\
\hline STM1771 & STM14_2141 & chaA & -1.77 & -5.97 & 3.31 & - & 36 & GTTAATATTITGGAA & $8.00 \mathrm{E}-05$ & $\begin{array}{l}\text { calcium/sodium:proton } \\
\text { antiporter }\end{array}$ \\
\hline STM1125 & STM14_1281 & putP & -8.81 & -3.4 & -3.46 & + & 234 & GTTAACACTTTTAAA & $9.50 \mathrm{E}-05$ & $\begin{array}{l}\text { major sodium/proline } \\
\text { symporter }\end{array}$ \\
\hline STM1091 & STM14_1237 & sop $B$ & -2.17 & -3.57 & -5.89 & + & 52 & GTTAACCCTGTTGAA & 8.00E-05 & secreted effector protein \\
\hline STM2866 & STM14_3463 & sprB & -6.06 & -2.32 & -3.51 & + & 281 & GTTAATGAAAGGGAA & $8.10 \mathrm{E}-06$ & transcriptional regulator \\
\hline STM4405 & STM14_5290 & $y+f J$ & -3.2 & -1.45 & -2.31 & - & 67 & GTTAATCATATGTGC & 3.30E-05 & $\begin{array}{l}\text { putative transcriptional } \\
\text { regulator }\end{array}$ \\
\hline STM4535 & STM14_5449 & - & -2.7 & -1.04 & -2.76 & - & 98 & GTTAACAGAGGGAAA & $9.50 \mathrm{E}-05$ & putative PTS permease \\
\hline STM4467 & STM14_5361 & & -1.83 & 1.02 & -2.07 & - & 271 & GTTAATTATTTGTTT & $6.50 \mathrm{E}-06$ & arginine deiminase \\
\hline STM1130 & STM14_1293 & nanM & -2.58 & 1.01 & -2.92 & + & 115 & GATAACTCCATGTAA & $8.00 \mathrm{E}-05$ & $\begin{array}{l}\text { putative inner membrane } \\
\text { protein }\end{array}$ \\
\hline STM4165 & STM14_5006 & rsd & 2.75 & 1.69 & 2.74 & - & 67 & GTTAACAACATGCCA & $1.20 \mathrm{E}-05$ & $\begin{array}{l}\text { anti-RNA polymerase } \\
\text { sigma } 70 \text { factor }\end{array}$ \\
\hline STM1728 & STM14_2091 & yciG & 1.68 & 1.95 & -2.11 & - & 261 & GTTAATGCATTGTTT & $1.50 \mathrm{E}-05$ & $\begin{array}{l}\text { putative cytoplasmic } \\
\text { protein }\end{array}$ \\
\hline STM0292 & STM14_0341 & - & 1.18 & 2.12 & 2.18 & - & 248 & GTTCATCAAATGTAG & $6.80 \mathrm{E}-05$ & putative RHS-like protein \\
\hline STM2220 & STM14_2744 & yejG & 5.84 & 2.41 & 2.94 & + & 64 & GTCAATGATGTGTTA & $6.80 \mathrm{E}-05$ & hypothetical protein \\
\hline STM1770 & STM14_2140 & chaB & 2.07 & 3.64 & -2.12 & + & 245 & GTTAATATTITGGAA & 8.00E-05 & cation transport regulator \\
\hline \multirow[t]{3}{*}{ STM1211 } & \multirow{3}{*}{ STM14_1385. } & \multirow[t]{3}{*}{$n d h$} & \multirow[t]{3}{*}{7.09} & \multirow[t]{3}{*}{3.58} & \multirow[t]{3}{*}{2.24} & - & 44 & GTTAATTAAAAGTTA & 1.10E-06 & \multirow{3}{*}{$\begin{array}{l}\text { respiratory NADH } \\
\text { dehydrogenase } 2\end{array}$} \\
\hline & & & & & & + & 65 & GTTAATTAAAGGCTA & $1.00 \mathrm{E}-05$ & \\
\hline & & & & & & - & 33 & ATTAACCAATTGTTA & $9.50 \mathrm{E}-05$ & \\
\hline \multirow{2}{*}{$\begin{array}{c}\text { STM1746. } \\
\text { S }\end{array}$} & \multirow{2}{*}{ STM14_2110 } & oppA & -7.87 & -2.46 & -3.08 & + & 318 & GTTAACAAAATTGTA & 1.00E-05 & oligopeptide transport \\
\hline & & & & & & - & 327 & GTTAACCAATTCTCT & $6.80 \mathrm{E}-05$ & \\
\hline STM1818 & STM14_2199 & $f a d D$ & -1.56 & -1.85 & 2.56 & + & 75 & GTTAATATAATGTTA & $1.00 \mathrm{E}-05$ & long-chain-fatty-acid-CoA \\
\hline & & & & & & + & 64 & GTTAACGACTTGTTI & 1.00E-05 & \\
\hline STM3692 & STM14_4451 & $\| d P$ & -13.27 & -2.11 & -6.83 & - & 125 & GTTAACCAGATGTTA & $2.00 \mathrm{E}-06$ & L-lactate permease \\
\hline & & & & & & + & 136 & GTTAACTATTTGTTG & 5.20E-06 & \\
\hline & & & & & & - & 173 & GTTAATTTAATGAAA & 1.90E-05 & \\
\hline STM1303 & STM14_1582 & $\arg D$ & -2.63 & -1.11 & -2.95 & - & 40 & GTTATTTATATGTTA & $2.80 \mathrm{E}-05$ & bifunctional succinylornithine \\
\hline & & & & & & + & 112 & GTTTATGCAATGTTA & 5.70E-05 & \\
\hline
\end{tabular}




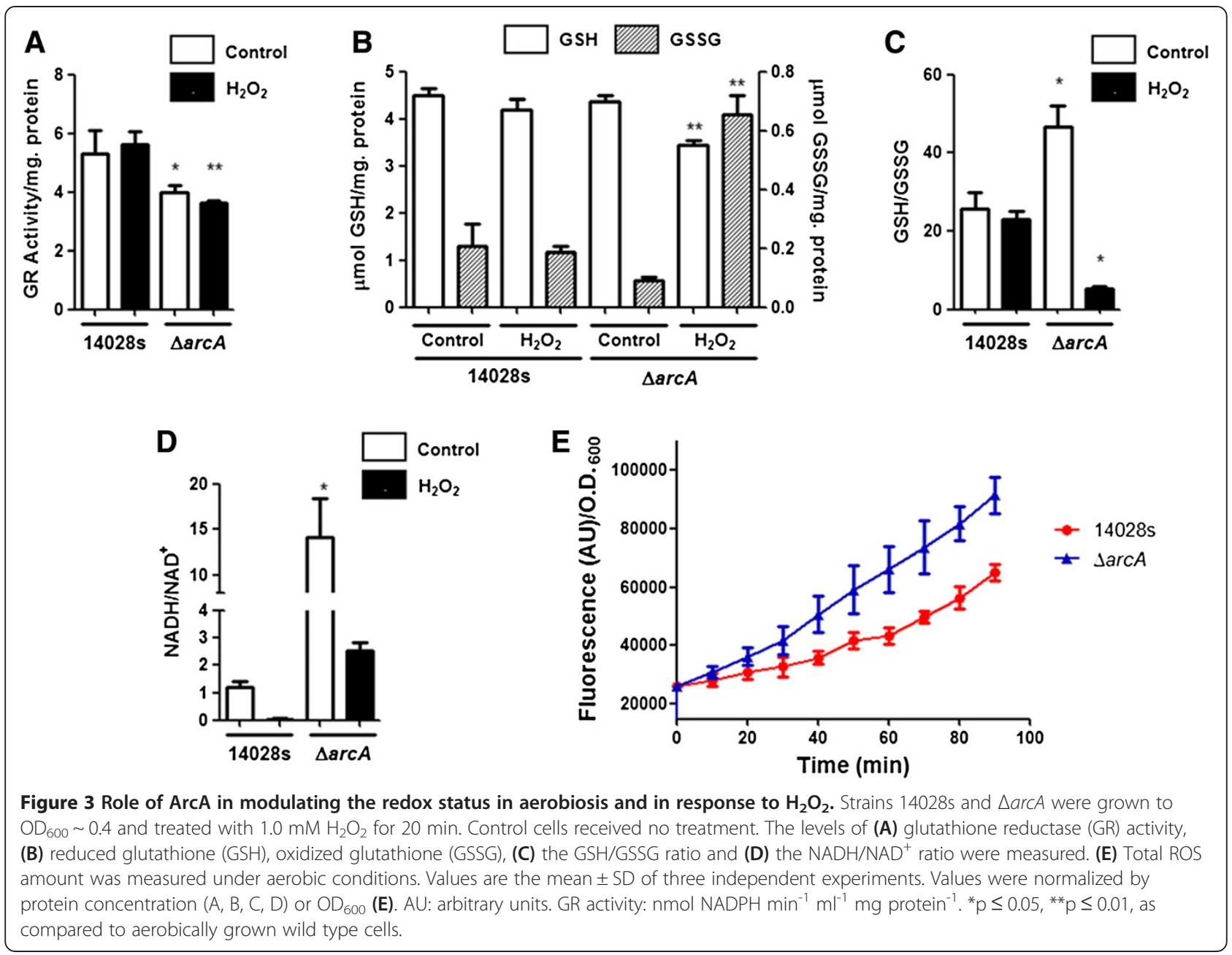

evaluate the mechanism underlying the role of ArcA in response to ROS [7]. Herein, we report the first genome-wide study addressing the role of ArcA in response to $\mathrm{H}_{2} \mathrm{O}_{2}$ under aerobic conditions. ArcA regulates different genes after ROS exposure in aerobiosis, under aerobic growth in rich media and under anaerobiosis (Figure 1, 2 and 4; Additional file 2: Table S2). In this discussion, we will focus on the genes and pathways regulated by ArcA that contribute to ROS resistance of $S$. Typhimurium. A full list of the genes regulated by ArcA in aerobiosis with and without $\mathrm{H}_{2} \mathrm{O}_{2}$ is provided in Additional file 2: Table S2.

\section{Role of ArcA in ROS scavenging}

The $S$. Typhimurium genome codes for several genes that degrade $\mathrm{H}_{2} \mathrm{O}_{2}$ or organic hydroperoxide, including catalases ( $k a t G, k a t E$ and $k a t N)$, alkyl hydroperoxide reductases (ahpCF and tsaA) [47] and a glutathionedependent peroxidase (btuE) [48]. Only ahpF and katE are predicted to be regulated by ArcA in aerobiosis with or without $\mathrm{H}_{2} \mathrm{O}_{2}$, respectively (Additional file 2: Table S2).
Expression of $a h p F$ and $k a t E$ is also known to be regulated by RpoS $[49,50]$. Neither katN nor $\operatorname{sod} A$, previously described as members of the ArcA regulon under anaerobic conditions $[8,51]$, were found to be regulated by ArcA under aerobic conditions with or without $\mathrm{H}_{2} \mathrm{O}_{2}$ treatment. These results are in agreement with studies in $E$. coli that demonstrate that an $\operatorname{arc} A$ mutant does not show defects in $\mathrm{H}_{2} \mathrm{O}_{2}$ scavenging [7].

\section{Role of ArcA in maintaining GSH and thioredoxin levels}

ArcA positively regulates the expression of the genes gor (GR) and $\operatorname{tr} x B$ (thioredoxin reductase) in aerobiosis with $\mathrm{H}_{2} \mathrm{O}_{2}$, but not without the toxic compound (Figure 2 and 4 Additional file 2: Table S2). However, the levels of GR activity were lower in the $\operatorname{arc} A$ mutant strain grown under aerobic conditions (Figure 3A), but not the levels of GSH turnover (Figure 3B). This suggests that there are other unidentified factors that alter GR activity in the $\operatorname{arc} A$ mutant grown under aerobic conditions, since there are no differences in the transcript levels of the gene gor between strains 14028s and $\triangle \operatorname{arcA}$ (Additional 


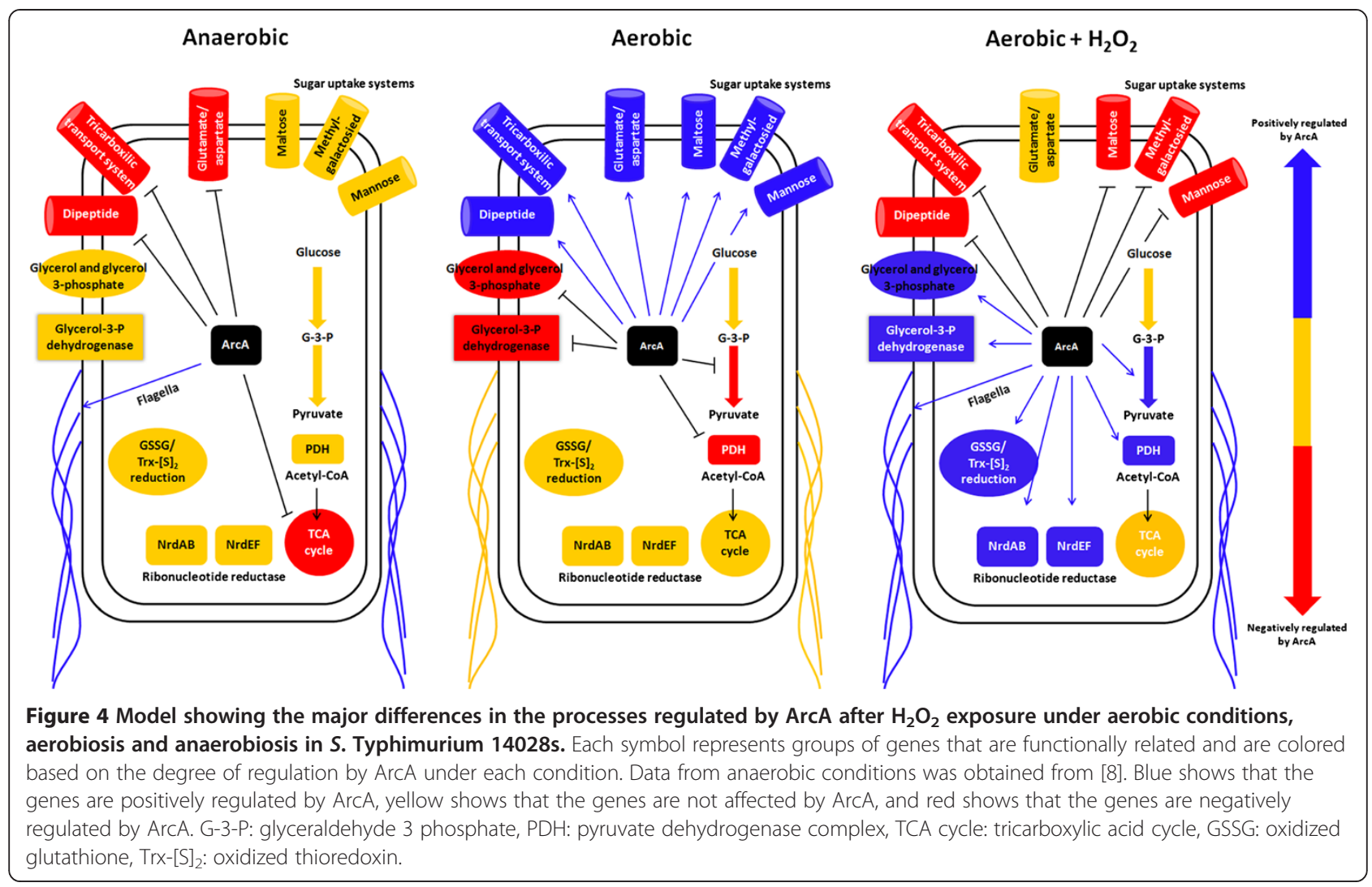

file 2: Table S2). In addition, this indicates that the lower levels of GR activity in the $\operatorname{arcA}$ mutant grown under aerobic conditions are sufficient to cope with GSH turnover, and the effect is only evident when GSH oxidation is increased, as when cells are exposed to peroxide.

In E. coli, OxyR regulates gor expression [6], while the expression of $\operatorname{tr} x B$ has not been determined under this condition. Two putative ArcA binding sites were predicted at the promoter region of $\operatorname{tr} x B$ (Table 2). Glutathione and thioredoxin reductases are required to reduce GSSG and thioredoxin in a NADPH-dependant manner, which in their reduced form participate in the reduction of cellular disulfide bonds [45] and of oxidized glutaredoxin. An E. coli $\Delta$ gor mutant has a slight sensitivity towards paraquat and cumene hydroperoxide [52], while in stationary phase a $\triangle \operatorname{tr} x B$ strain shows $\mathrm{H}_{2} \mathrm{O}_{2}$ sensitivity [53]. However, a double $\triangle$ gor $\triangle \operatorname{tr} x B$ mutant grows extremely poorly under aerobic conditions and presents increased alkaline phosphatase activity, indicative of increased disulfide bond formation, most likely due to increased ROS [54]. Since an aerobically grown $\triangle \operatorname{arcA}$ mutant treated with $\mathrm{H}_{2} \mathrm{O}_{2}$ has lower transcript levels of gor and $\operatorname{trx} B$, lower GR activity and lower GSH levels (Figure 2 and $3 \mathrm{~A}, \mathrm{~B}$ and $\mathrm{C}$ ), this might result in increased disulfide bond formation, protein inactivation and contribute to the increased sensitivity towards ROS. Since GSH is abundant in the cell and is readily oxidized by $\mathrm{H}_{2} \mathrm{O}_{2}$, this leads to a decrease in the levels of reduced glutathione, shifting the target of oxidation from GSH to essential macromolecules, leading to cell death [55]. This may occur earlier in a $\triangle \operatorname{arcA}$ mutant, as its level of "protective" GSH is low, caused by decreased GR activity.

\section{ArcA and nucleotide metabolism}

The pathways that showed the highest changes in the $\triangle \operatorname{arc} A$ mutant treated with $\mathrm{H}_{2} \mathrm{O}_{2}$ under aerobic conditions were purine and pyrimidine metabolism (Figure 4, Table 1). The major differences are found in the expression of the $n r d A B$ and $n r d E F H I$ operons, coding for aerobic and alternative aerobic ribonucleotide reductase, respectively. In $E$. coli and $S$. Typhimurium, NrdAB is indispensable for growth under aerobic conditions while NrdEF is not functional [56]. In the aerobically grown wild type strain, $n r d A B$ was repressed while $n r d E F$ was up-regulated after $\mathrm{H}_{2} \mathrm{O}_{2}$ exposure, in agreement with studies in E. coli and S. Typhimurium 4/74 [41,43], while the regulation was lost in the $\triangle \operatorname{arc} A$ mutant under the same conditions (Additional file 2: Table S2). NrdEF is usually repressed by Fur. However, in response to $\mathrm{H}_{2} \mathrm{O}_{2}$, this Fur repression is abolished and the apoprotein form of IscR upregulates expression of the operon [44]. This suggests that in response to $\mathrm{H}_{2} \mathrm{O}_{2}$ under aerobic conditions, ArcA may act together with Apo-IscR, up-regulating the $n r d E F H I$ operon. 


\section{ArcA and carbon metabolism}

Under aerobic conditions, the transcript levels of genes coding proteins of glycerolipid metabolism, glycolysis and the PDH complex were higher in the $\triangle \operatorname{arcA}$ mutant than in the wild type strain (Figure 2 and 4, Additional file 2: Table S2). This suggests that the flux through glycolysis and the levels of acetyl-CoA could be increased in the $\triangle \operatorname{arc} A$ strain. Two studies conducted in E. coli measured the flux through the PDH complex in a $\triangle \operatorname{arcA}$ mutant under aerobic conditions with different results. One showed that there was an increase in the flux through the PDH complex [14] while in the other no differences were observed [57], although both studies determined that there was an increase in the flux through the TCA cycle. Our analysis showed that the NADH/NAD ${ }^{+}$ ratio was 2 -fold higher in the aerobically grown $\triangle \operatorname{arcA}$ mutant than in the wild type strain (Figure 3D). After $\mathrm{H}_{2} \mathrm{O}_{2}$ exposure, the NADH/NAD ${ }^{+}$ratio decreased in the wild type and $\triangle \operatorname{arcA}$ strain, but in the latter the levels remained higher than in the wild type strain under aerobic conditions (Figure 3D). Since NADH can reduce $\mathrm{Fe}^{3+}$ to $\mathrm{Fe}^{2+}$ in vitro [56], and elevated $\mathrm{NADH}$ levels result in increased sensitivity towards $\mathrm{H}_{2} \mathrm{O}_{2}$ [58], the higher basal levels of NADH in the $\triangle \operatorname{arcA}$ mutant in aerobiosis and after $\mathrm{H}_{2} \mathrm{O}_{2}$ treatment may increase $\mathrm{Fe}^{+2}$ turnover, fueling the Fenton reaction (the formation of $\mathrm{OH}$, and $\mathrm{Fe}^{3+}$ from the nonenzymatic reaction of $\mathrm{Fe}^{2+}$ with $\mathrm{H}_{2} \mathrm{O}_{2}$ ) and leading to higher levels of ROS-derived damage.

In the respiratory chain, NADH dehydrogenase II (encoded by $n d h$ ) generates $\mathrm{O}_{2}^{-}$and $\mathrm{H}_{2} \mathrm{O}_{2}$ by oxidation of its reduced $\mathrm{FADH}_{2}$ cofactor [58]. In an aerobically grown $\triangle \operatorname{arcA}$ strain, the levels of NADH and the $n d h$ transcript (Additional file 2: Table S2) are higher than in the wild type strain under the same condition (Figure 3D). We therefore speculated that production of intracellular ROS might be increased. In agreement, a $\operatorname{arc} A$ mutant presents statistically significant increased levels of total ROS as compared to the wild type strain $14028 \mathrm{~s}$ (Figure 3E). These higher levels of ROS might present further disadvantages for the bacterium when exposed to $\mathrm{H}_{2} \mathrm{O}_{2}$. However, several other sources of intracellular ROS besides NADH dehydrogenase II may also contribute to the higher levels of ROS observed in the $\triangle \operatorname{arcA}$ mutant, such as fumarate-reducing flavoenzymes [59].

\section{Conclusion}

We identified the ArcA regulon in $S$. Typhimurium under aerobic growth with and without $\mathrm{H}_{2} \mathrm{O}_{2}$, and show that ArcA coordinates a response that includes changes in cellular-, glutathione-, thioredoxin-, NADH- and glycerolipid metabolism. These changes contribute to $\mathrm{H}_{2} \mathrm{O}_{2}$ resistance by modulating the reducing potential of the cell.

\section{Additional files}

Additional file 1: Probing the ArcA regulon under aerobic/ROS conditions in Salmonella enterica serovar Typhimurium.

A) Supplementary methods. B) Figure S1: Characterization of the mechanism of ArCA in response to ROS. Measurement of the transcript and protein levels of $\operatorname{arcA}$ by qRT-PCR and Western blot, respectively. Determination of CFU/ml in strains $14028 \mathrm{~s}, \triangle \operatorname{arcA}, \triangle \operatorname{arcA}:$ : cat/pBR::arcA, and $\triangle \operatorname{arcA}:: c a t / p B R:: \operatorname{arcAD54A}$, after $\mathrm{H}_{2} \mathrm{O}_{2}$ exposure.

C) Table S1: Validation of microarray data using qRT-PCR of randomly selected genes. Fold changes are given for the selected genes in response to hydrogen peroxide in the different genetic backgrounds as determined by qRT-PCR and microarray analysis.

D) Supplementary references [60]

Additional file 2: Table S2. Table of genes that showed intensity values over the background. Fold changes are given for every gene in response to $\mathrm{H}_{2} \mathrm{O}_{2}$ in the different genetic backgrounds.

\section{Competing interests}

The author(s) declare that they have no competing interests.

\section{Author's contributions}

EHM and CPS conceived the project. EHM and PD conducted the analysis of microarray data and prediction of regulated pathways. EHM, BC and ILC performed the experiments. FG, RL and SP conducted partial data analysis. EHM, SP, MM and CPS wrote the paper. All authors read and approved the final manuscript. The authors declare no conflict of interest.

\section{Acknowledgments}

This work was supported by grants from FONDECYT \#1120384 (to CPS), Universidad Andres Bello DI-34-11/R (to CPS), DI-24-12/I (to EHM) and DI-19$12 / I$ (to $B C$ ). EHM and $B C$ received doctoral fellowships by CONICYT and MECESUP UAB0802 additionally to EHM. The authors wish to thank Dr. Claudio Vásquez for critical reading the manuscript.

\section{Author details}

'Laboratorio de Microbiología Molecular, Facultad Ciencias Biológicas, Universidad Andres Bello, Santiago, Chile. ${ }^{2}$ Department of Microbiology and Molecular Genetics, B240 Medical Sciences Building, University of California, Irvine, CA 92697, USA. ${ }^{3}$ Present address: Great Lakes Bioenergy Research Center, University of Wisconsin-Madison, Madison, Wisconsin, USA. ${ }^{4}$ Present address: Department of Biomolecular Chemistry, University of WisconsinMadison, Madison, Wisconsin, USA.

Received: 26 February 2013 Accepted: 16 September 2013 Published: 17 September 2013

\section{References}

1. Mackaness GB, Blanden RV, Collins FM: Host-parasite relations in mouse typhoid. J Exp Med 1966, 124:573-583.

2. Fridovich I: The biology of oxygen radicals. Science 1978, 201:875-880.

3. Hassett D, Cohen M: Bacterial adaptation to oxidative stress: implications for pathogenesis and interaction with phagocytic cells. FASEB J 1989, 3:2574-2582.

4. Imlay J: Pathways of Oxidative Damage. Annu Rev Microbiol 2003, 57:395-418.

5. Canvin J, Langford PR, Wilks KE, Kroll JS: Identification of sodC encoding periplasmic [CuZn]-superoxide dismutase in Salmonella. FEMS Microbiol Lett 1996, 136:215-220

6. Christman MF, Morgan RW, Jacobson FS, Ames BN: Positive control of a regulon for defenses against oxidative stress and some heat-shock proteins in Salmonella typhimurium. Cell 1985, 41:753-762.

7. Loui C, Chang AC, Lu S: Role of the ArCAB two-component system in the resistance of Escherichia coli to reactive oxygen stress. BMC Microbiol 2009, 9:183.

8. Evans MR, Fink RC, Vazquez-Torres A, Porwollik S, Jones-Carson J, McClelland M, Hassan HM: Analysis of the ArcA regulon in anaerobically grown Salmonella enterica sv. Typhimurium. BMC Microbiol 2011, 21:11-58. 
9. Lu S, Killoran PB, Fang FC, Riley LW: The global regulator ArcA controls resistance to reactive nitrogen and oxygen intermediates in Salmonella enterica serovar Enteritidis. Infect Immun 2002, 70:451-461.

10. Wong SM, Alugupalli KR, Ram S, Akerley BJ: The ArcA regulon and oxidative stress resistance in Haemophilus influenzae. Mol Microbiol 2007 64:1375-1390

11. luchi S, Matsuda Z, Fujiwara T, Lin EC: The $\operatorname{arcB}$ gene of Escherichia coli encodes a sensor-regulator protein for anaerobic repression of the arc modulon. Mol Microbiol 1990, 4:715-727.

12. Iuchi S, Lin EC: Purification and phosphorylation of the Arc regulatory components of Escherichia coli. J Bacteriol 1992, 174:5617-5623.

13. Rolfe MD, Ter Beek A, Graham Al, Trotter EW, Shahzad Asif HM, SysMO-SUMO, Sanguinetti G, de Mattos JT, Poole RK, Green J: Transcript profiling and inference of Escherichia coli K-12 ArcA activity across the range of physiologically relevant oxygen concentrations. J Biol Chem 2011, 286:10147-10154.

14. Alexeeva S, Hellingwerf K, Mattos JT: Requirement of ArcA for Redox Regulation in Escherichia coli under Microaerobic but Not Anaerobic or Aerobic Conditions. J Bacterio/ 2003, 185:204-209.

15. Georgellis D, Kwon O, Lin EC: Quinones as the Redox Signal for the Arc Two-Component System of Bacteria. Science 2001, 292:2314-2316.

16. Malpica R, Franco B, Rodriguez C, Kwon O, Georgellis D: Identification of a quinone-sensitive redox switch in the ArcB sensor kinase. Proc Natl Acad Sci 2004, 101:13318-13323.

17. Bekker M, Alexeeva S, Laan W, Sawers G, Mattos JT, Hellingwerf K: The ArcBA Two-Component System of Escherichia coli Is Regulated by the Redox State of both the Ubiquinone and the Menaquinone Pool. J Bacteriol 2010, 191:746-754.

18. Peña-Sandoval G, Georgellis D: The ArcB Sensor Kinase of Escherichia coli Autophosphorylates by an Intramolecular Reaction. J Bacterio/ 2010, 192:1735-1739.

19. Georgellis D, Lynch AS, Lin EC: In vitro phosphorylation study of the arc two-component signal transduction system of Escherichia coli. J Bacteriol 1997, 179:5429-5435.

20. Kwon O, Georgellis D, Lin EC: Phosphorelay as the Sole Physiological Route of Signal Transmission by the Arc Two-Component system of Escherichia coli. J Bacteriol 2000, 182:3858-3862.

21. Lynch AS, Lin EC: Transcriptional control mediated by the ArcA twocomponent response regulator protein of Escherichia coli: characterization of DNA binding at target promoters. J Bacterio/ 1996, 178:6238-6249.

22. Jeon $Y$, Lee $Y$, Han J, Kim J, Hwang D: Multimerization of Phosphorylated and Non-phosphorylated ArcA is Necessary for the Response Regulator Function of the Arc Two-Component Signal Transduction System. J Biol Chem 2001, 276:40873-40879.

23. Oshima T, Aiba H, Masuda Y, Kanaya S, Sugiura M, Wanner BL, Mori H, Mizuno T: Transcriptome analysis of all two-component regulatory system mutants of Escherichia coli K-12. Mol Microbiol 2002, 46:281-291.

24. Liu X, De Wulf P: Probing the ArcA-P modulon of Escherichia coli by whole genome transcriptional analysis and sequence recognition profiling. J Biol Chem 2004, 279:12588-12597.

25. Salmon KA, Hung S, Steffen NR, Krupp R, Baldi P, Hatfield GW, Gunsallus R: Global gene expression profiling in Escherichia coli K12. J Biol Chem 2005, 280:15084-15096.

26. Gao H, Wang $X$, Yang ZK, Palzkill T, Zhou J: Probing regulon of ArcA in Shewanella oneidensis MR-I by integrated genomic analyses. BMC Genomic 2008, 9:42.

27. Calderón IL, Morales E, Caro NJ, Chahuán CA, Collao B, Gil F, Villareal JM, Ipinza F, Mora GC, Saavedra CP: Response regulator ArcA of Salmonella enterica serovar Typhimurium downregulates the expression of OmpD, a porin facilitating uptake of hydrogen peroxide. Res Microbio/ 2011, 162:214-222.

28. Morales EH, Calderón IL, Collao B, Gil F, Porwollik S, McClelland M, Saavedra CP: Hypochlorous acid and hydrogen peroxide-induced negative regulation of Salmonella enterica serovar Typhimurium ompW by the response regulator ArcA. BMC Microbiol 2012, 12:63.

29. Berney M, Weilenmann HU, Ihssen J, Bassin C, Egli T: Specific growth rate determines the sensitivity of Escherichia coli to thermal, UVA, and solar disinfection. Appl Environ Microbiol 2006, 72:2586-2593.

30. Santiviago CA, Reynolds MM, Porwollik S, Choi S, Long F, AndrewsPolymenis HL, McClelland M: Analysis of pools of targeted Salmonella deletion mutants identifies novel genes affecting fitness during competitive infection in mice. PLoS Pathog 2009, 5:e1000477.

31. Xia XQ, McClelland M, Porwollik S, Song W, Cong X, Wang Y: WebArrayDB: cross-platform microarray data analysis and public data repository. Bioinformatics 2009, 25:2425-2429.

32. Saeed Al, Sharov V, White J, Li J, Liang W, Bhagabati N, Braisted J, Klapa M, Currier T, Thiagarajan M, Sturn A, Snuffin M, Rezantsev A, Popov D, Ryltsov A, Kostukovich E, Borisovsky I, Liu Z, Vinsavich A, Trush V, Quackenbush J: TM4: a free, open-source system for microarray data management and analysis. Biotechniques 2003, 34:374-378.

33. Dabney A, Storey JD, Warnes GR: qvalue: Q-value estimation for false discovery rate control. $R$ package version 1.26.0. http://www.bioconductor. org/packages/release/bioc/html/qvalue.html.

34. Subramanian A, Tamayo P, Mootha VK, Mukherjee S, Ebert BL, Gillette MA, Paulovich A, Pomeroy SL, Golub TR, Lander ES, Mesirov JP: Gene set enrichment analysis: a knowledge-based approach for interpreting genome-wide expression profiles. Proc Natl Acad Sci 2005, 102:15545-15550.

35. Pfaffl MW: A new mathematical model for relative quantification in realtime RT-PCR. Nucleic Acids Res 2001, 29:e45.

36. Wang X, Gao H, Shen Y, Weinstock GM, Zhou J, Palzkill T: A high-throuput percentage-of-binding strategy to measure energies in DNA-protein interactions: application to genome-scale discovery. Nucleic Acids Res 2001, 36:4863-4871.

37. Jarvik T, Smillie C, Groisman EA, Ochman H: Short-term signatures of evolutionary change in the Salmonella enterica serovar Typhimurium 14028 genome. J Bacteriol 2010, 192:560-567.

38. Turatsinze JV, Thomas-Chollier M, Defrance M, van Helden J: Using RSAT to scan genome sequences for transcription factor binding sites and cisregulatory modules. Nat Protoc 2008, 3:1578-1588.

39. Echave P, Tamarit J, Cabiscol E, Ros J: Novel antioxidant role of alcohol dehydrogenase E from Escherichia coli. J Biol Chem 2003, 278:30193-30198.

40. Janssen $R$, van der Straaten T, van Diepen A, van Dissel JT: Responses to reactive oxygen intermediates and virulence of Salmonella typhimurium. Microbes Infect 2003, 5:527-534.

41. Wright JA, Tötemeyer SS, Hautefort I, Appia-Ayme C, Alston M, Danino V, Paterson GK, Mastroeni P, Ménager N, Rolfe M, Thompson A, Ugrinovic S, Sait L, Humphrey T, Northen H, Peters SE, Maskell DJ, Hinton JC, Bryant CE: Multiple redundant stress resistance mechanisms are induced in Salmonella enterica serovar Typhimurium in response to alteration of the intracellular environment via TLR4 signalling. Microbiology 2009, 155:2919-2929.

42. Nelson DL, Cox MM: Glycolysis, gluconeogenesis, and the pentose phosphate pathway. In Lehninger, Principles of Biochemistry. 4th edition. Edited by Lehninger AL. New York: WH Freeman; 2004:521-559.

43. Monje-Casas F, Jurado J, Prieto-Alamo MJ, Holmgren A, Pueyo C: Expression analysis of the nrdHIEF operon from Escherichia coli. Conditions that trigger the transcript level in vivo. J Biol Chem 2001, 276:18031-18037.

44. Martin JE, Imlay JA: The alternative aerobic ribonucleotide reductase of Escherichia coli, NrdEF, is a manganese-dependent enzyme that enables cell replication during periods of iron starvation. Mol Microbio/ 2011, 80:319-334.

45. Carmel-Harel O, Storz G: Roles of glutathione- and thioredoxin-dependent reduction systems in the Escherichia coli and Saccharomyces cerevisiae responses to oxidative stress. Annu Rev Microbiol 2000, 54:439-461.

46. Imlay JA, Fridovich I: Assay of metabolic superoxide production in Escherichia coli. J Biol Chem 1991, 266:6957-6965.

47. Hébrard M, Viala JP, Méresse S, Barras F, Aussel L: Redundant hydrogen peroxide scavengers contribute to Salmonella virulence and oxidative stress resistance. J Bacteriol 2009, 191:4605-4614.

48. Arenas FA, Díaz WA, Leal CA, Pérez-Donoso JM, Imlay JA, Vásquez CC: The Escherichia coli btuE gene, encodes a glutathione peroxidase that is induced under oxidative stress conditions. Biochem Biophys Res Commun 2010, 398:690-694.

49. Golubeva YA, Slauch JM: Salmonella enterica serovar Typhimurium periplasmic superoxide dismutase sodCl is a member of the PhoPQ regulon and is induced in macrophages. J Bacterio/ 2006, 188:7853-7861.

50. Ibanez-Ruiz M, Robbe-Saule V, Hermant D, Labrude S, Norel F: Identification of RpoS $\left(\sigma^{S}\right)$-regulated genes in Salmonella enterica serovar Typhimurium. J Bacteriol 2000, 182:5749-5756. 
51. Tardat B, Touati D: Two global regulators repress the anaerobic expression of MnSOD in Escherichia coli::Fur (ferric uptake regulation) and Arc (aerobic respiration control). Mol Microbiol 1991, 5:455-465.

52. Alonso-Moraga A, Bocanegra A, Torres JM, López-Barea J, Pueyo C: Glutathione status and sensitivity to GSH-reacting compounds of Escherichia coli strains deficient in glutathione metabolism and/or catalase activity. Mol Cell Biochem 1987, 73:61-68.

53. Takemoto T, Zhang QM, Yonei S: Different mechanisms of thioredoxin in its reduced and oxidized forms in defense against hydrogen peroxide in Escherichia coli. Free Radic Biol Med 1998, 24:556-562.

54. Prinz WA, Aslund F, Holmgren A, Beckwith J: The role of the thioredoxin and glutaredoxin pathways in reducing protein disulfide bonds in the Escherichia coli cytoplasm. J Biol Chem 1997, 272:15661-15667.

55. Henard CA, Bourret TJ, Song M, Vázquez-Torres A: Control of the redox balance by the stringent response regulatory protein promotes antioxidant defenses of Salmonella. J Biol Chem 2010, 285:36785-36793.

56. Jordan A, Aragall E, Gibert I, Barbe J: Promoter identification and expression analysis of Salmonella typhimurium and Escherichia coli nrdEF operons encoding one of two class I ribonucleotide reductases present in both bacteria. Mol Microbiol 1996, 19:777-790.

57. Perrenoud A, Sauer U: Impact of global transcriptional regulation by ArcA, ArcB, Cra, Crp, Cya, Fnr, and Mlc on glucose catabolism in Escherichia coli. J Bacteriol 2005, 187:3171-3179.

58. Messner KR, Imlay J: The identification of primary sites of superoxide and hydrogen peroxide formation in the aerobic respiratory chain and sulfite reductase complex of Escherichia coli. J Biol Chem 1999, 274:10119-10128.

59. Korshunov S, Imlay JA: Two sources of endogenous hydrogen peroxide in Escherichia coli. Mol Microbiol 2010, 75:1389-1401.

60. Uzzau S, Figueroa-Bossi N, Rubino S, Bossi L: Epitope tagging of chromosomal genes in Salmonella. Proc Natl Acad Sci 2001, 98:15264-15269.

doi:10.1186/1471-2164-14-626

Cite this article as: Morales et al:: Probing the ArcA regulon under aerobic/ROS conditions in Salmonella enterica serovar Typhimurium. BMC Genomics 2013 14:626.

\section{Submit your next manuscript to BioMed Central and take full advantage of:}

- Convenient online submission

- Thorough peer review

- No space constraints or color figure charges

- Immediate publication on acceptance

- Inclusion in PubMed, CAS, Scopus and Google Scholar

- Research which is freely available for redistribution 